\title{
Osteoinductive Potential of the rhBMP-2 in Soft Tissues
}

\author{
Potencial Osteoinductor de la rhBMP-2 en Tejidos Blandos \\ "João Paulo Mardegan Issa; "Cássio do Nascimento; "Rodrigo Edson dos Santos Barbosa; **Mamie Mizusaki Iyomasa \& \\ *** Rubens Ferreira de Albuquerque Junior
}

ISSA, M. J. P.; NASCIMENTO, C.; BARBOSA, S. R. E.; IYOMASA, M. M. \& ALBUQUERQUE JR. R. F. Osteoinductive potential of te rhBMP-2 in soft tissues. Int. J. Morphol., 25(1):125-128, 2007.

SUMMARY: The rhBMP-2 is an osteoinductive protein used in the reconstructive with the objective to create newly formed bone. The aim of this study was to confirm the rhBMP-2 osteoinductive capability, when implanted in soft tissues. The results showed that the protein used in this study is highly osteoinductive.

KEY WORDS: Bone repair; rhBMP-2; Osteoinduction; Soft tissue.

\section{INTRODUCTION}

The development of new procedures for bone regeneration has been made possible by advances in molecular biology. Since Urist (1965) demonstrated that demineralized bone matrix could increase the formation of cartilage and bone at ectopic sites, many investigators have attempted to clarify the active component of the matrix. Urist \& Strates (1971) identified it as a growth factor protein that induces ectopic bone formation and named it bone morphogenetic protein (BMP). After the BMP genes were cloned by Wozney et al. (1988), attempts to use recombinant human bone morphogenetic proteins (rhBMPs) for bone formation have been performed. Wang et al. (1988), found that rhBMP-2 formed bone and cartilage when implanted in rat muscles with insoluble bone matrix by inducing muscle cells to differentiate into chondrocytes and osteoblasts. Furthermore, bone defects in the dog (Toriumi et al., 1991) and rat (Yasko et al., 1992) have been repaired by implanting rhBMP-2 with insoluble bone matrix.

The main clinical application of rhBMP-2 is in reconstructive surgery, and it may be applied not only to the heterotopic or orthotopic normal tissues, but also to compromised tissues, such as musculocutaneous flaps, surgical scars, or irradiated tissues. These tissues have compromised blood circulation and are susceptible to infection. Some clinical applications of purified rhBMP have been reported (Sailer \& Kolb, 1994; Johnson et al., 1988; Johnson et al., 1990). Up to now, little is known about the clinical applications of rhBMP-2. Among others, Boyne reported the use of rhBMP-2 for reconstruction of extensive bone defects in primates (Boyne, 1996; Boyne et al., 1997, 1998, 1999). However, the activity of rhBMP-2 was less than one tenth that of purified BMP (Bessho et al., 1999; Wozney, 1989).

The purpose of present study was to evaluate the osteogenic potential of the complex rhBMP-2/collagen matrix involved in chitosan gel when implanted at abdominal rat muscle.

\section{MATERIAL AND METHOD}

This study followed the requirements of the Ethics Committee on the Use of Animals in Experimentation at the University of São Paulo, Brazil.

I- Identification and characterization of the rhBMP-2.

\section{A- Electrophorese and Western blot analysis.}

It was performed the electrophoretic protein characterization using a polyacrilamyde gel developed by Sigma electrophorese system (St. Louis, MO, USA), according to Laemmli method (1970). 
After electrophoretic transfer of proteins from SDSPAGE gels to nitrocellulose membranes, these were saturated with 5\% skimmed milk in TBS-Tween $0.1 \%$ (Tris $20 \mathrm{mM}$, $\mathrm{pH} 7.4, \mathrm{NaCl} 137 \mathrm{mM}$, and Tween $200.1 \%$ ) and soaked at room temperature for $3 \mathrm{~h}$. Then they were incubated overnight at $4{ }^{\circ} \mathrm{C}$ with rhBMP-2 primary antibodies against (Santa Cruz; dilution 1/1000). After three washes in TBSTween-milk solution, the membranes were incubated with the corresponding secondary antibody peroxidase (1/2000) for 1 hour, room temperature. After, they were processed using the Amersham ECL kit following the manufacturer's instructions.

I. B. Spectrophotometer analysis. The purity of rhBMP-2 was assessed by polyacrylamide gel electrophoresis followed by spectrophotometric determinations (Beckman-DU-70, USA) in the stained gel band. The spectrophotometer provides a standard graphic of the electrophoretic gel strain, supplying through the proteins locations and area measurement, the percentage of sample purity.

II. Substances. Chitosan (Hidagem HCMF, Cognis, Spain) gel was prepared at dispersing $8.3 \mathrm{mg}$ of chitosan in $1.0 \mathrm{ml}$ of water solution followed of acidifying with acetic acid $(1.0 \%)$.

It was used a collagen sponge sufficient to carry $15 \mu \mathrm{g}$ of rhBMP-2 or without this protein, in sequence this material was involved in a chitosan capsule.

III. Animals. It was used 6 rats, divided into 2 equal groups:

Group 1: Collagen sponge with $15 \mu \mathrm{g}$ of rhBMP-2 involved in a chitosan capsule;

Group 2: Collagen sponge, without rhBMP-2, involved in a chitosan capsule;

The capsules were implanted at the abdominal region, between the muscular and cutaneous tissue, in these rats.

The animals were fed with commercial rat chow and had access to food and water ad libitum.

III. A. Surgical procedure. The rats were anaesthetized with standard anesthetic cocktail consisting of ketamine hydrochloride $(60 \mathrm{mg} / \mathrm{Kg})$ and xylazine $(5 \mathrm{mg} / \mathrm{Kg})$, administered intraperitoneally. Surgery was performed using aseptic techniques. An incision was made through the skin, subcutaneous tissues and the abdominal muscle were exposed. The chitosan capsule was inserted between these tissues.

III. B. Sacrifice and animals' perfusion. After two weeks, the animals were anaesthetized with urethane $37.5 \%(0.4 \mathrm{~mL} /$
$100 \mathrm{~g}$ ) and submitted to perfusion. This procedure involves an intracardiac infusion of saline solution $(100 \mathrm{~mL})$ followed by $10 \%$ formalin and paraformaldehyde $4 \%$ in phosphate buffer $0.2 \mathrm{M}(100 \mathrm{~mL})$. The soft tissue, muscular and cutaneous tissues were removed for histological processing (Fig. 1A).

III. C. Histological processing. The soft tissues were immersed in $4 \%$ paraformaldehyde/ $0.1 \mathrm{M}$ phosphate-buffer solution for $24 \mathrm{~h}$, and neutralized by a 5\% sodium sulphate solution. After imbedded in paraffin, the specimens were cut into $6 \mu \mathrm{m}$ thick sections and stained with hematoxylineosin and Trichrome-Masson. The histological sections were evaluated with the objective to verify if that is possible to observe new formed bone in this tissue. It was used an optical microscope (Leica MZ125 connected to a digital camera, Germany).

\section{RESULTS AND DISCUSSION}

It was performed the Western blot analysis with the objective to confirm, by a laboratorial method, if this sample was really the recombinant human bone morphogenetic protein, type 2 (rhBMP-2) and the spectrophotometer analysis with the aim to verify the purity of grade in this sample. The data indicated that this sample is really rhBMP2, by Western blot analysis (Fig. 1B), and it has $86 \%$ of purity grade, by spectrophotometer analysis.

It was observed that the rhBMP-2 used in this study, seems to be able to induce formation of new bone tissue (Figs. 1C and 1D), this substance is an osteoinduction protein that acts chemotactically in the differentiation of mesenchymal cells into bone synthesizing cells (Lee 1997; Ripamonti et al., 1997; Wozney, 1998; Ripamonti \& Duneas, 1998; Ducy \& Karsenty, 2000; Schilephake, 2002; Arosarena \& Collins, 2005). Although the bone morphogenetic protein, type 2 , is able to promote osteoinduction by itself (Desilets et al., 1990), many other studies about bone repair have shown that the process is optimized by association of the protein to a sustained release carrier (Issa et al., 2006).

The protein purity grade is an important factor directly influencing indexes of new bone formation. In this study, gel electrophoretic analysis followed by spectrophotometric determinations indicated that rhBMP-2 was highly pure, (86\%) of purity, thus explaining the large concentration of newly formed bone. According to Wang et al., active principle purity affects not only indexes of new tissue formation but also the presence or absence of specific cellular types. 


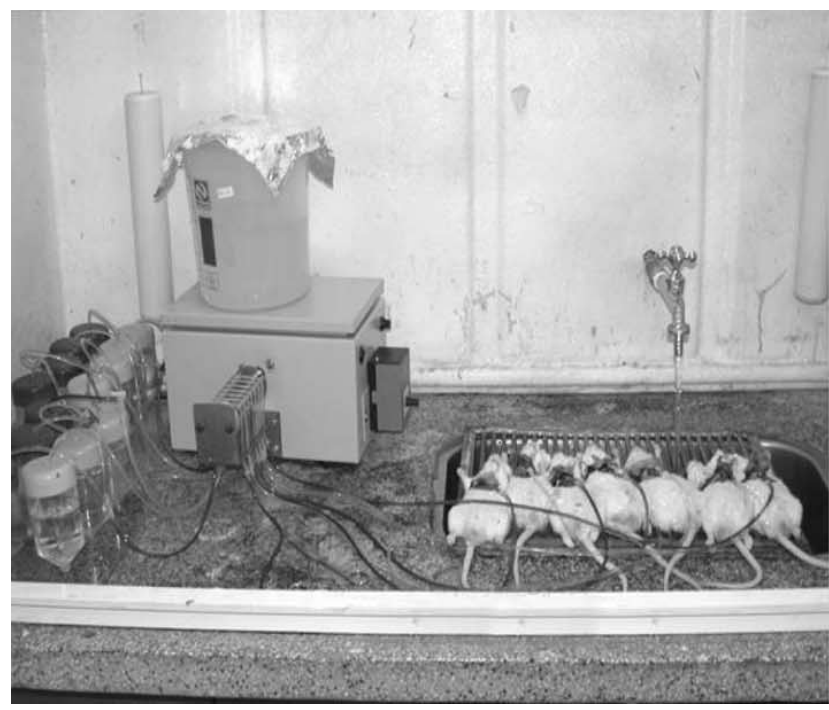

Fig. 1A. Representative photomicrograph showing the animals' perfusion.

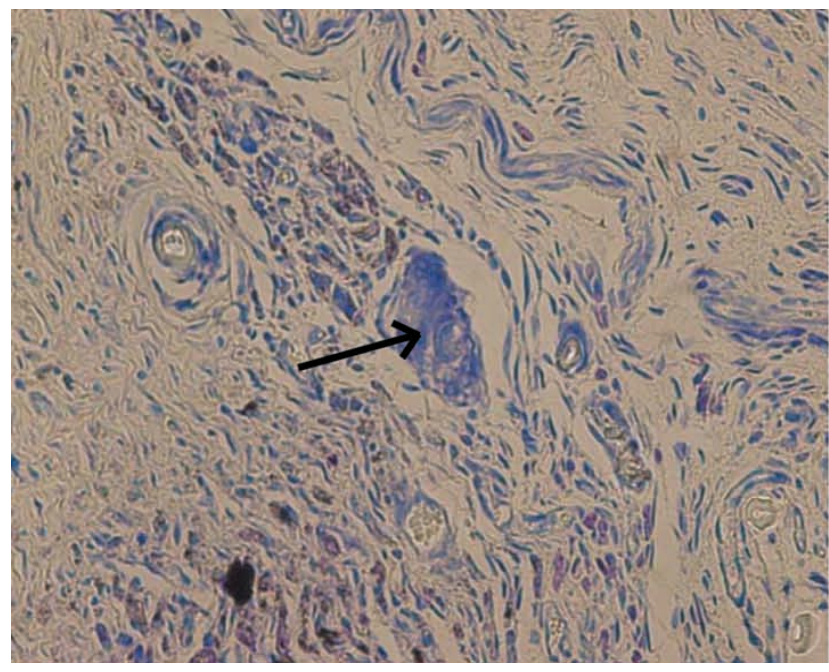

Fig. 1. C. Representative photomicrograph showing the new formed bone (arrow) in the soft tissue (500X of original magnification, Trichrome-Masson stain).

The method used in this study showed that, rhBMP2 incorporated with collagen sponge and involved in chitosan gel was able to produce new formed bone over the soft tissues when was compared with the group that the rhBMP-2 was not present.

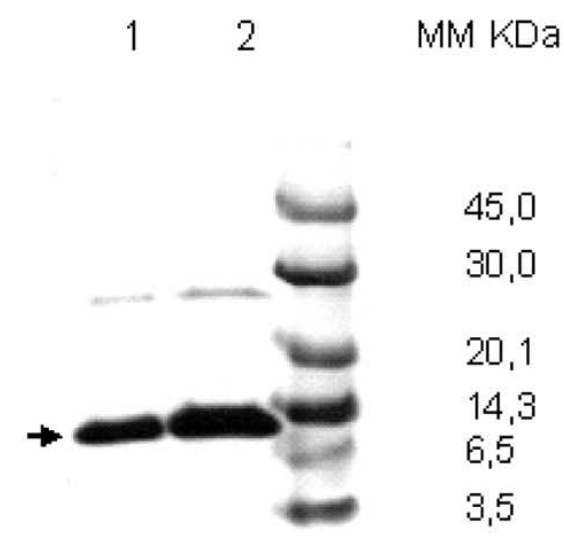

Figure 1B. Representative photomicrograph of the Western blot analysis, showing the molecular weight $(10.5 \mathrm{KDa})$ of the rhBMP2 (arrow).

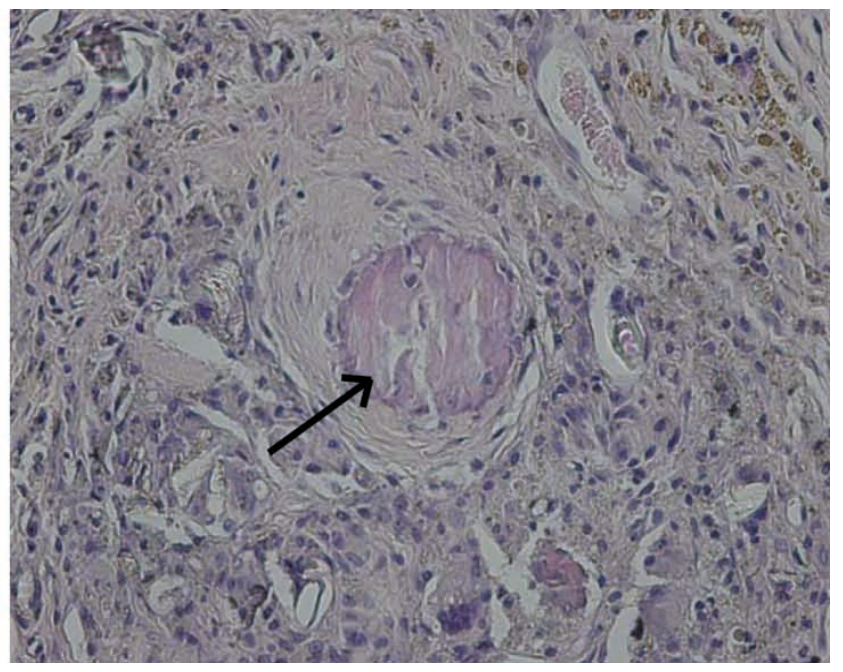

Fig. 1. D. Representative photomicrograph showing the new formed bone (arrow) in the soft tissue (500X of original magnification, HE stain).

Thus, it is possible to use this sequential methodology, in soft tissues, with the objective to verify the osteoinduction potential of the rhBMP-2.

Acknowledgements. We are grateful to FAPESP (Fundação de Amparo à Pesquisa do Estado de São Paulo) for financial support (04/12013-0).

ISSA, M. J. P.; NASCIMENTO, C.; BARBOSA, S. R. E.; IYOMASA, M. M. \& ALBUQUERQUE JR. R. F. Potential osteoinductor rhBMP-2 en tejidos blandos. Int. J. Morphol., 25(1):125-128, 2007.

RESUMEN: La proteína oseoinductora rhBMP-2 es usada en cirugías reconstructoras, con la finalidad de crear tejido óseo neoformado. El objetivo de este estudio fue confirmar la capacidad oseoinductora de la rhBMP-2, cuando fue implantada en tejidos blandos. Los resultados mostraron que la proteína usada en este estudio es altamente oseoinductora.

PALABRAS CLAVE: Reparación ósea; rhBMP-2; Oseoinducción; Tejido blando. 


\section{REFERENCES}

Arosarena, O. A. \& Collins, W. L. Bone regeneration in the rat mandible with bone morphogenetic protein-2: a comparison of two carriers. Otolaryngol. Head. Neck. Surg., 132:592-7, 2005.

Bessho, K.; Kusumoto, K.; Fujimura, K.; Konishi, Y.; Ogawa, Y.; Tani, Y. \& Iizuka, T. Comparison of recombinant and purified human bone morphogenetic protein. Br. J. Oral. Maxillofac. Surg., 37:2-5, 1999.

Boyne, P. J. Animal studies of application of rhBMP-2 in maxillo-facial reconstruction. Bone., (1 suppl):S83-92, 1996.

Boyne, P. J.; Marx, R. E. ; Nevins, M.; Triplett, G. ; Lazaro, E.; Lilly, L. C.; Alder, M. \& Nummikoski, P. A feasibility study evaluating rhBMP2/absorbable collagen sponge for maxillary sinus floor augmentation. Int. J. Periodontics. Restorative. Dent., 17:11-25, 1997.

Boyne, P. J.; Nath, R. \& Nakamura, A. Human recombinant BMP-2 in osseous reconstruction of simulated cleft palate defects. Br. J. Oral. Maxillofac. Surg., 36:84-90, 1998.

Boyne, P. J.; Nakamura, A. \& Shabahang, S. Evaluation of the long-term effect of function on rhBMP-2 regenerated hemimandibulectomy defects. Br. J. Oral. Maxillofac. Surg., 37: 344-52, 1999.

Desilets, C. P.; Marden, L. J.; Patterson, A. L. \& Hollinger, J.O. Development of synthetic bone-repair materials for craniofacial reconstruction. J. Craniofac. Surg, 1:150-3, 1990.

Ducy, P. \& Karsenty, G. The family of bone morphogenetic proteins. Kidney. Int., 57:2207-14, 2000.

Issa, J. P. M.; Nascimento, C.; Barbosa, R. E. S.; Mello, A. S. S. \& Iyomasa, M. M. TGF-beta and new bone formation. Int. J. Morphol., 24:32330, 2006.

Johnson, E. E.; Urist, M. R. \& Finerman, G. A. Bone morphogenetic protein augmentation grafting of resistant femoral nonunions. Clin. Orthop., 230:257-65, 1988.

Johnson, E. E.; Urist, M. R. \& Finerman, G. A. Distal metaphyseal tibial nonunion. Deformity and bone loss treated by open reduction, internal fixation, and human bone morphogenetic protein (hBMP). Clin. Orthop., 250:234-40, 1990.

Laemmli, U. K. Cleavage of structural proteins during the assembly of the head of bacteriophage T4. Nature., 227:680-5, 1970.

Lee, M. B. Bone morphogenetic proteins: Background and implications for oral reconstruction. A review. J. Clin. Periodontol., 24:355-65, 1997.

Ripamonti, U.; Duneas, N.; Van Den Heever, B.; Bosch, C. \& Crooks, J. Recombinant transforming growth factors- $\beta 1$ induces endochondral bone in the baboon and synergizes with recombinant osteogenic protein-1 (Bone Morphogenetic Protein-7) to initiate rapid bone formation. J. Bone. Miner. Res., 12:1584-95, 1997.
Ripamonti, U. \&Duneas, N. Tissue morphogenesis and regeneration by morphogenetic proteins. Plastic. Reconst. Surg., 101:227-39, 1998.

Sailer, H. F. \& Kolb, E. Application of purified bone morphogenetic protein (BMP) in cranio-maxillo-facial surgery. J. Craniomaxillofac. Surg., 22: 2-11, 1994.

Schilephake, H. Bone growth factors in maxillofacial skeletal reconstruction [Review]. Int. J. Oral. Maxillofac. Surg., 31:469-84, 2002.

Toriumi, D. M.; Kotler, H. S.; Luxenberg, D. P.; Holtrop, M. E. \& Wang, E.A. Mnadibular reconstruction with a recombinant bone-inducing factor. Functional, histologic and biomechanical evaluation. Arch. Otolaryngol. Head. Neck. Surg., 117:1101-12, 1991.

Urist, M. R. Bone: Formation by autoinduction. Science, 150: 893-99, 1965.

Urist, M. R. \& Strates, B.S. Bone morphogenetic protein. J. Dent. Res., 50:1392-406, 1971

Wang, E. A.; Rosen, V.; D’Alessandro, J. S.; Bauduy, M.; Cordes, P.; Harada, T.; Israel, D.; Hewick, R. M.; Kerns, K.; Lapan, P.; Luxenberg, D. P.; McQuaid, D.; Moutsatsos, I.; Nove, J. \& Wozney, J.M. Recombinat human bone morphogenetic protein induces bone formation. Proc. Natl. Acad. Sci. USA., 87:2220-4, 1990.

Wozney, J. M.; Rosen, V.; Celeste, A. J.; Mitsock, L. M.; Whitters, M. J.; Kriz, R. W.; Hewick, R. M. \& Wang, E.A. Novel regulators of bone formation: molecular clones and activities. Science, 242: 1528-34, 1988.

Wozney, J. M. Bone morphogenetic protein. Prog. Growth. Factor. Res., 1:267-80, 1989.

Wozney, J.M. The bone morphogenetic protein family: Multifunctional cellular regulators in the embryo and adult. Eur. J. Oral. Sci., 106:1606, 1998.

Yasko, A. W.; Lane, J. M.; Fellinger, E. J.; Rosen, V.; Wozney, J. M. \& Wand, E. A. The healing of segmental bone defects induced by recombinant human bone morphogenetic protein (rhBMP-2). A radiographic, histological and biomechanical in rats. J. Bone. Joint. Surg. Am.; 74: 659-70, 1992. Erratum. 74: 1111, 1992.

Correspondence to:

Dr. João Paulo Mardegan Issa

Faculdade de Odontologia de Ribeirão Preto -USP

Depto. Morfologia, Estomatologia e Fisiologia

Av. Café s/n

CEP 14040-904

Monte Alegre

Ribeirão Preto- SP

BRASIL

E-mail: jpmissa@forp.usp.br

Received: 14-10-2006

Accepetd: 22-12-2006 